\title{
犬腎同種移植における $\alpha_{2}$-globulin, $\gamma$-globulin
}

\author{
および細胞毒力価の変動
}

付. 蛍光抗体直接法による $\gamma$-globulin の移植腎内吸着について

慶応義熟大学医学部泌尿器科学教室 長 谷 川 昭*
(主任 大越正秋教授)

ALTERATIONS OF $\alpha_{2}$-GLOBULIN, $\gamma$-GLOBULIN AND CYTOTOXIC
ANTIBODY IN CANINE RENAL ALLOGRAFT
WITH SPECIAL REFERENCE TO $\gamma$-GLOBULIN DEPOSITION
O THE GRAFT USING DIRECT IMMUNOFLUORESCENT TECHNIQUE

Akira Hasegawa

Department of Urology, Keio University, School of Medicine

(Director: Prof. Dr. Masaki Ohkoshi)

For the purpose of early serological diagnosis predicting renal allograft rejection, detektion of changes in serum $\alpha_{2}$-globulin, serum $\gamma$-globulin and BUN, detection of cytotoxic antibodies and histological and immunopathological studies (direct immunofluorescent technique using anti-canine- $\gamma$-globulin-rat-globulin-F.I.T.C.) were performed in four groups of canine renal allografts.

Group 1. Bilateral nephrectomy and renal allotransplantation.

Group 2. Group 1 with immunosuppression.

Group 3. Unilateral nephrectomy and renal allotransplantation, followed by graftectomy 7 days after transplantation.

Group 4. Group 3 with immunosuppression.

Immunosuppression was carried out with prednisolone $5 \mathrm{mg} / \mathrm{kg} /$ day and azathioprine $2 \mathrm{mg} / \mathrm{kg} /$ day Aminobenzyl penicillin $250 \mathrm{mg} / \mathrm{kg} /$ day and methylchlorophenyl isoxazolil penicillin $250 \mathrm{mg} /$ day were given for five days after the operation to prevent infection.

1. $\alpha_{2}$-globulin increased after renal allotransplantation and the graftectomy in almost all cases. However because of possible overlapping with $\alpha_{2}$-Acute-Phase-globulin, it seems that immediate postoperative rise of $\alpha_{2}$-globulin level does not indicate directly acute or superacute rejection of the grafts.

2. Serum $\gamma$-globulin fraction increased with the increase of BUN or after the destruction of the grafts was completed. Significant increase of $\gamma$-globulin was observed after graftectomy in some cases. Rise of $\gamma$-globulin fraction in groups 2 and 4 was not so marked with contrast to groups 1 and 3.

3. Appearance of cytotoxic antibodies in the serum following renal allotransplantation indicated graft rejection. On the other hand, there were some cytotoxin-negative cases although histological and immunopathological studies revealed graft destruction and azotemia (cytotoxin false negative). Cytotoxin false negative cases might be due to (a) no common histocompatibility antigens between a kidney donor and lymphocyte donor dogs because lymphocyte donor dogs were relatively small in number. (b) absorption of the cytotoxic antibodies by the grafts which contain very large amount of antigen. Serum cytotoxic antibodies were detected after graftectomy, or low titers of cytotoxin frequently increased more significantly after graftectomy. (c) The cytotoxin could be so-called C-N-A-P antibodies.

4. The appearance of cytotoxic antibodies and the increase of serum $\gamma$-globulin level were not always

*大学院学生 
simultaneous.

5. It seems to be possible to predict graft rejection by cytotoxic titration in near future. So storage method of the lymphocytes and collection of pure lymphocyte suspension should be popularized for higher and earlier cytotoxic antibodies detection, if test lymphocytes are obtained from the same graft donor.

6. Kidney sections of four groups of renal allotransplants were examined by immunofluorescence technique to detect deposits of $\gamma$-globulin. They were detected from fifth days after transplantation, and they appeared in the glomerular tufts, peritubular capillaries and venules. As the rejection progressed $\gamma$-globulin deposits appeared in the relatively large vessels such as interlobular arteries and arcuate arteries, especially in the endothelium and internal elastic layer. In completely rejected allografts, there were $\gamma$-globulin deposits in the interstitial tissue of the cortex and medulla. But no specific fluolescence was demonstrated in the tubular cells. $\gamma$-globulin was shown in a significant number of rejected kidneys in comparison with the non-rejecting kidneys. There were two types of $\gamma$-globulin deposition in the glomeruli, linear and granular. The demonstration of these deposits suggests that humoral antibodies play an important role in the rejection of canine renal allografts.

\section{I 緒 言}

腎同種移植に扔ける拒否反応の診断は，移植患者を管 理する際に, 免疫抑制反応, ドナーの選択の問題ととも に, もつとも重要なことの一つである. ことに免疫抑制 療法下に頻発する感染症との鑑別䛦断は，その治療の方 向が逆の立場にあるだけに，より確実な鑑別法を必要と する。

一方, 同種移植時の拒否反応に括ける液性抗体の果す 役割が，近年ようやく脚光を浴び始めてきたが，拒否反 応診断の手掛りとしての血清学的診断法は，まだその端 緒についたばかりである.

Medawar ${ }^{122)}$ の独創的な実験によつて, 同種移植臟器 に起こる拒否反応が，免疫反応によることが証明された が, その本態については, 同種移植免疫が, 感作血清の 注射によつて受動的に移入できないこと, 生きた感作り ンパ球の移入により受動的に同種移植免度の移入が可能 であるこど)などから，同種移植免疫は細胞性抗体が働 く遅延型アルルギーの代表例のごとく理解され，体液性 抗体の果す役割は，無視され，あるいは第 2 義的烤克 られて近年に至つたのである。ところが1962年，Najarian, Feldman ${ }^{4)}$ は, Milipore chamber に封入した 感作リンパ球によつて，移植された皮膚の拒否反応が促 進されることを報告した．続いて，Terasaki ${ }^{5)}$ らはラ ッテを用いた実験で，Altman ${ }^{6}$ は犬を用いた腎同種移 植の実験で，いずれも感作されたリシピエントの血清 を，直接腎動脈に注入することによつて，移植免疫の血 清による受動的な移入に成功した. また，無グロブリン 血症の患者が，液性抗体を作ることが困難であることは 広く知られているが，そうした患者はまた，皮膚同種移
植片を拒否し難い7)，といら報告も加わり，臟器同種移 植の場で果す液性抗体の役割が次第に研究者の注意を惹 きつけるようになつてきた。

そうした移植抗体を，腎同種移植個体の血清中に検出 することができ，しかも，拒否反応との相関関係を追求 できたならば，それが，拒否反応の血清学的診断の $1 つ$ になりらると考光，犬を用いた腎同種移植の実験を行な い, 同時飞血清 $\alpha_{2}$-globulin, $\gamma$-globulin, cytotoxic antibodiesの経時的な検索を進め, それらと, BUN, 組 織学的拒否反応所見の程度, 特よび自家製抗犬- $\gamma$-globulin-家鬼-globulin-FITC を用いた蛍光抗体直接法に よる免疫組織学的検索を併せ行なつて得られた結果につ いて報告する.

\section{II 実験材料および方法}

1. 犬腎同種移植実験群

実験群として, 次の 4 群に分けた.

$\mathrm{A}$ 群 : 同種移植 (移植と同時に 両側腎摘出術を施行 し, 免疫抑制処置を行なわない群)

B 群：免疫抑制群 (Prednisolone $2 \mathrm{mg} / \mathrm{kg} /$ day +azathiopurine $5 \mathrm{mg} / \mathrm{kg} / \mathrm{day}$ )の免疫抑制処置を行なつた群）

C群：腎摘出術を片側にとどめ, 移植後 5〜9 日目に 移植腎摘出を行なつた群

$\mathrm{D}$ 群 : C 群と同様な実験犬に, B 群に行なつたと同様 の免疫抑制処置を行なつた群

2. 犬腎同種移植手技

体重10１5kgの雑種成犬を用い, Pentobarbital sodium $30 \mathrm{mg} / \mathrm{kg}$ の静脈麻酔を行なつた後, 気導確保のため

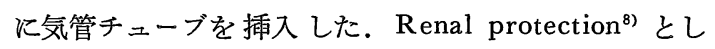
て, graft となる腎の摘出までに，0.33\%塩化ナトリウ 
ム加 $5 \%$ ブドウ糖液を体重 $1 \mathrm{~kg}$ たり 15 25ml 点滴静 注した。腎摘出術括よび骨盤腔内への腎同種移植は，正 中線切開により経腹腔的に行なつたが，犬に和ける皮下 出血はなかなか自然に止血しないことが多いため，でき るだけ丁寧に結紮止血した。腎の潅流には $10^{\circ} \mathrm{C}$ に冷却し た乳酸化リンゲル液 $100 \mathrm{ml}$ ， ヘパリン・ナトリウム 500 単位, 塩酸プロカイン $100 \mathrm{mg}^{9)}$ ，を用いた。腎の摘出に 際しては，血管の剝離をできる限り腎門部より遠く， すなわち腎動静脈の 起始部近くで血管を切断した。動 脈吻合は，中山式血管吻合器により，2 mm たは $3 \mathrm{~mm}$ 径 のリングを用い，外腸骨動脈との間に端端吻合。静脈 吻合は 6-0 血管縫合糸を用い手縫いで外腸骨静脈との 間に端側吻合を行ならか, 動脈と同様に中山式血管吻合 器（リング径 $4 \mathrm{~mm}$ ）を用いて端端吻合を行なつた．尿管 一膀脱吻合は Thompson 氏法を行なつた。な和術後， 感染症予防のために, aminobenzyl penicillin $250 \mathrm{mg} /$ day. + methylchlorophenyl isoxazalyl penicillin $250 \mathrm{mg} / \mathrm{day}$ の筋注を術後 5 日間毎日行なつた. 採血は, 術前および術後隔日に行ない, 血清分離後隇菌小試験管 4 本に分注し，検査を行なうまで $-20^{\circ} \mathrm{C}$ 冷凍保存し た. BUN の測定には Conway の微量拡散法によるク ロマトグラフペーパー法（ユニグラフ）を用い，血清総 蛋白の測定には，refractomor（日立蛋白濃度計）を用 いた。

\section{3． 血清蛋白分画・免疫電気泳動}

血清蛋白分画の定量は，電気泳動学会規定の，セルロ ーズアセテート膜電気泳動法による血清蛋白分画量法の 標準操作法 ${ }^{10}$ に従つて 行なつた。免疫電気泳動は抗血 清に，自家製抗犬家鬼血清を用いて，Peetoom ${ }^{11)}$ の方 法に従つて寒天を支持体として行なつた.

4。 細胞毒力価の測定

a ) 白血球浮遊液の作製

白血球浮遊液の作製は，Altman \& Simonsen の方 法 ${ }^{12)}$ 用いた。すず白血球ドナーとなる雑種成犬（5〜 8 頭)からへパリン加注射器で静脈血を採取した。血液と 同量の $8 \%$ glycerol を含む $1.5 \%$ polyvinylpyrrolidoneを加光てよく混和し，約 30 分間放置し，次に白血球 と赤血球の少数とが混じた桃色の上清だけを遠沈管に移 し，400 g， 6 分間遠心沈澱を行なつた. 次にこの遠心 沈澱を行なつた上清を捨て沈椬に，最初の血液量の $1 / 4$ 量 の tissue culture 用 medium を加光静かに混和する。 この操作で，混在する赤血球は溶血し，注とんど 100\% の白血球浮遊液が得られる (50 75\%がリンパ球)。この
白血球浮遊液の白血球数を血球計算板を用いて算定した 後, 白血球数が $6,000 \sim 8,000 / \mathrm{mm}^{3}$ になるように Difco hemagglutination bufferを加える. こうして得ら れた白血球は，トリパン・ブルー喰食検査では97〜 100 の viability を示し， $10^{\circ} \mathrm{C}$ 以下で操作され，保存され ていれば約 8 時間は cytoxic titer の測定に用いること ができる。

b ) Cytotoxic titer 測定手技 (test-tube-cytotoxictitration 中村変法 ${ }^{13}$ )

（i ) 被検血清を Difco hemagglutination buffer で倍数稀䣋し， $2^{0} \times$ から $2^{5} \times$ までの倍数稀釈系列を作 つた。

（ii） 被検稀釈血清（あるいは対照血清）……3 涫

$$
\left\{\begin{array}{l}
\text { 1)で作製した白血球浮遊液 } \\
\text { 補体 (Bacto complament) }
\end{array}\right.
$$

を小試験管内に入れ，ょく混和し $37^{\circ} \mathrm{C}$ 浴槽中で 60 分間 incubate する. 続いて $2 \%$ トリパンブルー 1 滴を加 光,さらに 30 分間 $37^{\circ} \mathrm{C}$ 浴槽中に放置し, 最後にフォルマ リン原液 2 滴を加觉て染色を停止させる。顕微鏡下で対

\section{表 1}
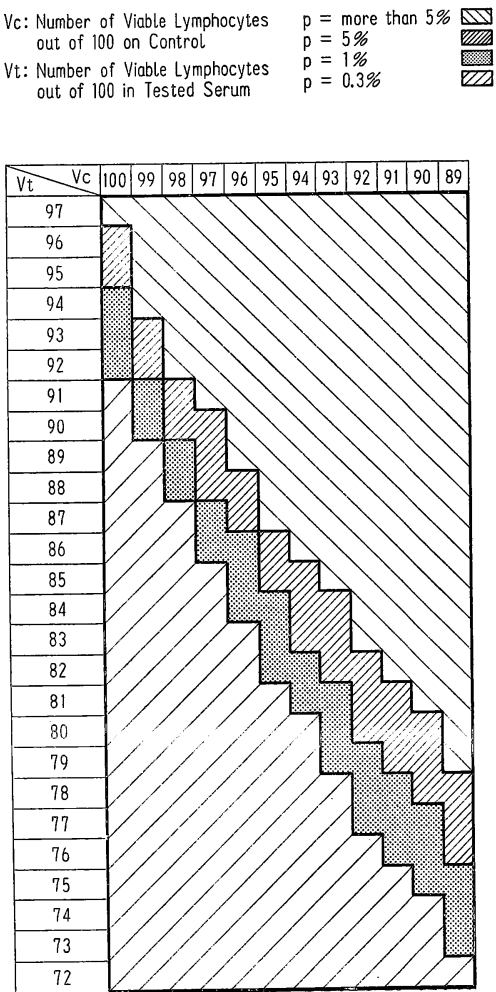
照血清和よび被検稀釈血清とともに incubate した白血 球 100 コのらち, 染色されていない細胞数を数兄, 両者 間で $\mathrm{X}^{2}$-test を行なつて（表一 1 ），P < 0.01で有意の差 を持つ最高の血清稀釈倍数をもつて，その血清の cytotoxic titer とした.

5. 蛍光抗体直接法 ${ }^{14) 15)}$

a) 蛍光抗体液 (Anti-dog $\gamma$-globulin-rabbit globulin-FITO) の作製

(i) 抗原：dog- $\gamma$-globulin は雑種成犬により得た 血清の34\%飽和硫安塩析を 4 回行なつた後, 生理食塩水 で透析したものを用いた。

(ii ) 家鬼抗血清の作製： dog- $\gamma$-globulin $10 \mathrm{mg}$ と Difco incomplete adjuvant とを週一回，体重 1.5 $2.0 \mathrm{~kg}$ の家鬼の足蹠皮下へ注射して免疫した. $9 \sim 13$ 週 免疫後試験採血で抗体価の上昇を，重積法による沈降反 応で確めた後, ブースターとして dog-r-globulin を 静脈注射し， 1 週間後に心穿刺により採血した。な拈， 家鬼は 3 羽を 1 グループとして免疫した.

（iii）抗血清より globulin への精製：50\%飽和硫安 塩析 1 回, 次いで34\%飽和硫安塩析を 3 回特こなつた. 透析は0.15M phosphate buffered salin で行なつた。 透析の終了した粗 globulin は Ouchterlony 寒天板法 および免疫電気泳動法をるつて。蛋白の性状および contamination の有無を調べ，refratometer にて蛋白量を 測定した.

（iv）蛍光色素 (fluorescein isothiocyanate) の標 識：抗体 (粗 globulin) への FITC の標識は， $0.5 \mathrm{M}$ 炭酸一重炭酸ソーダ緩衝液の存在下に $\mathrm{pH} 9.1$, 蛋白・色 素比 $100 ： 1 て ゙ ，$ 抗体溶液 の最終蛋白濃度が 1\%（10 $\mathrm{mg} / \mathrm{ml}$ ) の状態で, 水室内で一晚擋拌を 続けて行なつ た.

(v) 遊離色素の除去

遊離色素の除去は Cephadex G-25 column chromatography $(0.01 \mathrm{M} \mathrm{pH} 7.2$ phosphate buffered saline) を用いて行なつた。

(vi) DEAE-cellurose による非特異物質の除去

Cephadex G-25 column chromatography で得ら れ conjugate された蛋白溶液を，カーボワックスでい つたん濃縮して蛋白濃度を滈めた上 staining buffer で一晚透析後 DEAE-Cellurose による非持異物質の除 去涹つた.

DEAE-Cellurose $1 \mathrm{~N}-\mathrm{NaOH}$ で活性化し次に1N$\mathrm{HCl}$ で酸化し，ふたたび $1 \mathrm{~N}-\mathrm{NaOH} て ゙$ 洗い強アルカ
リ性に戻した後, 多量の蒸留水で洗い続ける. 蒸留水で 洗い，流出水がpH 8.4に近づけたところでpH 8.4，0.05 Mの phosphate buffer でよく洗いカラム管に充填す る.一方Conjugate は0.05M, pH 8.4 の同じphosphate bufferで一晚透析しておく. pH 8.4にされた conjugate をカラムに注入し, $200 \mathrm{ml}$ の0.05M, pH 8.4の phosphate buffer で elute すると，色素と結合していない 遊離の蛋白と, 蛋白と結合していない遊離の色素が先に 流出するからこれを捨てる.

第 1 分画のelute には, 0.05M, pH 6.4の phosphate buffer を用いフラクションコレクターで第 1 分画液を 収集し，次いで 0.1M，pH 6.4の phosphate buffer で elute して第 2 分画を兄, 第 3 分画の elute はpH 7.0, $1 \mathrm{~N}-\mathrm{NaCl}$ で行なつた。 今回の実験には, 非特異因子の 混存する第 2 , 第 3 分画で得られた conjugate 任使用 せず，第 1 分画で得られたるのの及を蛍光抗体液として 使用した. フラクッションコレクターを用いて収集され た各分画液は,引き続いてpH 7.2の staining bufferによ る透析を行なつた後, カーボワックス法で濃縮し, 最後 にふたたびpH 7.2の staining buffer で透析した後, ミ リポアフィルターを通して滅菌小試管に $1 \mathrm{ml}$ ずつ分往

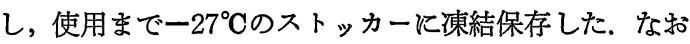
蛍光抗体液の最終蛋白濃度は $4 \mathrm{mg} / \mathrm{ml}$ であつた。

b) 低温処理パラフィン切片の作製

蛍光抗体法に用いる組織標本には, 浜島 ${ }^{15}$ らの推奨す る低温処理パラフィン切片を用いた。すすなわち移植腎剔 出後ただちに, 厚さ約 $2 \mathrm{~mm}$, 巾 $8 \mathrm{~mm} に$ 切り出し, ドライ アイス・アルコールであらかじめー $70^{\circ} \mathrm{C}$ 冷却された 95 $\%$ \%ノール中に投入し， 2 時間固定，次いでー $4{ }^{\circ} \mathrm{C} の$ $95 \%$ ×タールで一晚固定する. 脱水は一 $20^{\circ} \mathrm{C}$ の無水ア

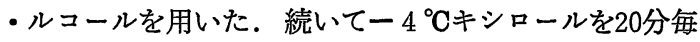
3 回通した後，融点 $56^{\circ} \mathrm{C} \sim 58^{\circ} \mathrm{C}$ のパラフィン溶液に 5 分 毎3 回通して包埋し、ブロックは使用するまでストッ カー内に保存した.

c ) 蛍光抗体による染色・写真撮影

パラフィンブロックから，ミクロトームを用いて $4 \mu$ の切片を作製（無蛍光スライドグラス使用）した後，脱 パラフィン，脱キシロールを型のごとく行ない，最後 に cold staining buffer でよく洗つてアルコールを落 した.

染色は室温, moist chamber 内で12時間行なつた. 染色終了後ただちに cold stainig buffer で切片をよ く洗い, glycerine buffer (無蛍光 glycerine 9： 
staining buffer.) で封入した.

観察およぽ写真撮影にはカール・ツァイス社製蛍光顕 微鏡装置を用い,フィルムはコダック社のエクタークロ 一ム。タイプB・フィルムを使用した。な和対照として 正常腎和よび抗体吸收試験 ${ }^{14)}$, blocking test ${ }^{14)}$ を行な つて蛍光の特異性の検討を行なつた。

\section{III 実験結果}

犬腎同種移植実験の各群における BUN, $\alpha_{2}$-globulin, $\gamma$-globulin の変動和よび cytotoxic antibody の 推移を図 1 〜図 4 に示す.

\section{1。A群（同種移植群，図一 1 参照）}

A-1 は術後12日目に死亡し，解剖の結果拒否反応によ る急性腎機能下全によつて死亡したものと推定された。 この例では，移植 5 日目から。血中に cytotoxic anti-

\section{図 1}

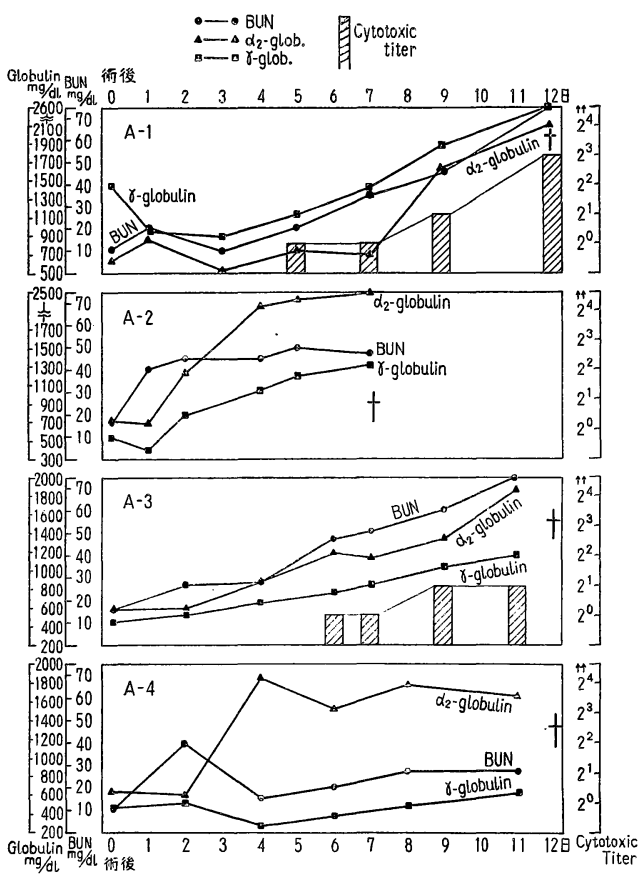

bodyが証明された。この抗体の出現は, 術後一過性に軽 度に上昇した BUN が術前値に戻り (術後 3 日目) ら たたび上昇しはじめるのと時を同じくしている．その力 価は，術後 7 日目までは $2{ }^{\circ} \times て ゙ ， 9$ 日目には $2^{1} \times$, 死 亡した 12 日目には $2^{3} \times$ に上昇している。 $\alpha_{2}$-globulin は移植直後に一過性に軽度 の上昇を示したが，術後 7 日目まではま涪術前值（642mg/dl）を保ち，術後 9 日目
から急激な上昇を示した。すなわら術後 9 日目には 1,6 $38 \mathrm{mg} / \mathrm{dl}$ ，術後12日目には $2,122 \mathrm{mg} / \mathrm{dl}$ と $231 \%$ も の増加を 示した。一方 $\gamma$-globulin は，術後 3 日目までは減少 $(1,453 \mathrm{mg} / \mathrm{dl} \rightarrow 898 \mathrm{mg} / \mathrm{dl})$, 乞の後は BUN の上昇とほ とんど平行して増加し，そのまま死亡するまでに上昇線 を迻つた。術後12日目には $2,600 \mathrm{mg} / \mathrm{dl}$ と，79\%の増加を 示した.

A-2 は移植後 7 日目に尿管一膀胱吻合部の縫合不全で 死亡した例であるが，移植腎の組織学的検索では，明ら かに拒否反応所見を呈していながらも，血中に cytotoxic antibodyは証明できなかつた。BUN は，移植翌日 から死亡時ま例40～50mg/dl であつたが， $\alpha_{2}$-globulin， $\gamma$-globulin は，移植後 2 日目から上昇しはじめ。いず れも $100 \%$ 以上の増加を見ている。

A-3 は移植後12日目に拒否反応によつて死亡した例で ある. 移植後 6 日目に初めて流血中に cytotoxic antiody が証明され，BUN の上昇と時を同じくしている。 力価は 6 日目， 7 日目が $2{ }^{\circ} \times ， 9$ 日目，11日目が $2^{1} \times$

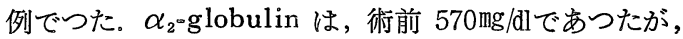
移植術後しだいに増加し，6日目には，1,190mg/dl，11 日目には $1,863 \mathrm{mg} / \mathrm{dl}$ と $227 \%$ の上昇を示した。

$\gamma$-globulin も術前の 455mg/dlから, ゆるやかに上昇 線をたどり，11日目には 1,170mg/dl と 158\%の增加を見 た.

A-4 は，術後12日目に腸重積を起こして死亡した例で あるが，移植腎は，一部梗塞を認めながらも，拒否反応 所見は軽微であつた例ででる。BUN は術後 2 日目に 40 $\mathrm{mg} / \mathrm{dl}$ と一過性に上昇したが 4 日目には $15 \mathrm{mg} / \mathrm{dl}$ に戻り， 以後死亡するまで，20〜27mg/dl に止まつた。 cytotoxic antibody は，死亡するまで血中に証明されず linもほとんど変動が認められなかつた。ただ $\alpha_{2}$-globu-

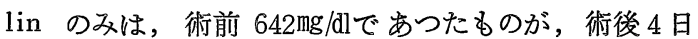
目飞突然 $1,840 \mathrm{mg} / \mathrm{dl}$ と急激に上昇し, それらが死亡時 ( $1,658 \mathrm{mg} / \mathrm{dl})$ まで続いた。

(小括)

A群の平均生存日数は 10.7 日で, その内直接拒否反 応で死亡したと考完られるのは，A-1，A-3 の2例であ る。移植腎の組織学的検索では，いずれの腎にも，程 度の差ことあれ拒否反応の所見が認められたが，A-2， A-4 の移植腎は，死亡時までその機能をある 程度充分 に果していたと推察される。Cytotoxicantibody は, A-1，A-3 の 2 例に和いて証明された。 その出現はBUN の上昇と時と同じくしていた。 $\alpha_{2}$-globlin は A 群 4 
頭の全例において術後䫒著な増加が認められたが， BUN との間に相関関係は見られなかつた. $\gamma$-globulin は，A-4 を除く他の 3 例に执いて，上昇する傾向を示し た.

\section{B群 (免疫抑制群 図 2 参照)}

B群は, prednisolone $2 \mathrm{mg} / \mathrm{kg} /$ day と azathioprine $5 \mathrm{mg} / \mathrm{kg} /$ day の免疫抑制処置を施した群である.

B-1 は移植術後12日目に創縫合不全で死亡した例であ るが，移植腎の組織学的検索で，拒否反応所見を認めな かつた例である. BUN は, 術前15mg/dlでくつたが, 術後 2 日目 $45 \mathrm{mg} / \mathrm{dl}$, その後下降 の傾向をとり術後 9 日目は

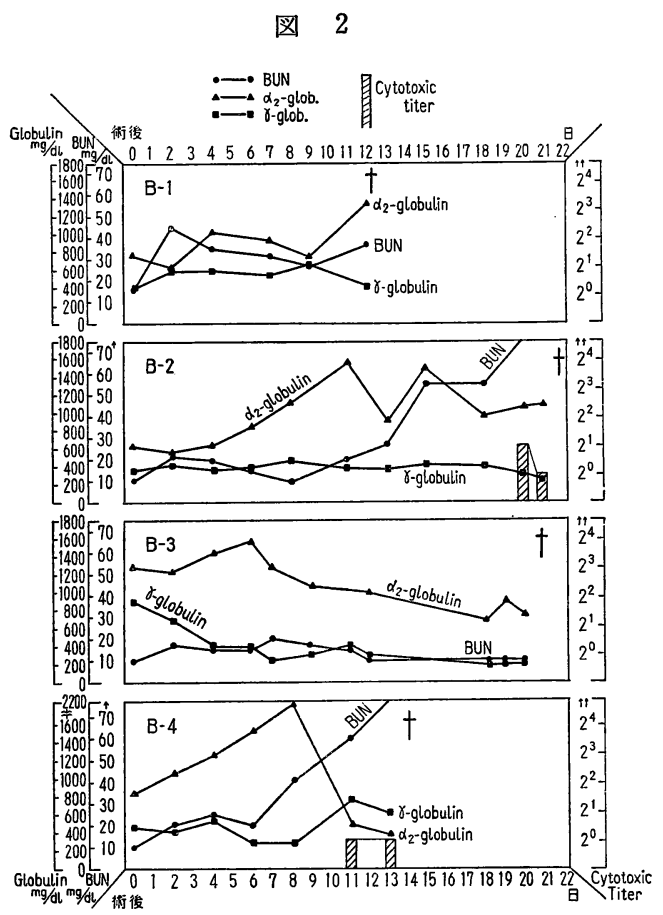

$27 \mathrm{mg} / \mathrm{dl}$ となつたが，死亡当日は $37 \mathrm{mg} / \mathrm{dl}$ と上昇傾向を示し た. $\alpha_{2}$-globulin は術後 4 日目に軽度の上昇を示した 後, 死亡当日は $1,358 \mathrm{mg} / \mathrm{dl}$ と, 術前值 ( $760 \mathrm{mg} / \mathrm{dl})$ の79 \%増加を見た. $\gamma$-globulin 分画には，見るべき変動な く, cytotoxic antibody は終始証明されなかつた。

B-2 は，移植術後22日目に拒否反応によつて死亡した が, cytotoxic antibody は, BUN がすでに75mg/dl以 上に上昇した術後20日目になつてはじめて血中に証明さ

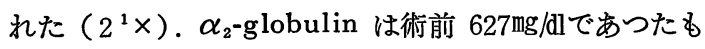
のが，術後漸次上昇し術後 11 日目には $1,566 \mathrm{mg} / \mathrm{dl}$ と上昇 したが，ふたたびやや下降し死亡前日の術後21日目には 1,080mg/dl となつた， $\boldsymbol{\gamma}$-globulin は術前 343mg/dlで術 後は汪とんど平行線を巡り，術後14日目からはやや下降 気味となり，術後21日目には $248 \mathrm{mg} / \mathrm{dl}$ と，28\%の低下を 示した.

B-3 は, 移植術後21日目に死亡するまで, 移植腎は良 好な機能を営み, BUN は術後 7 日目に $20 \mathrm{mg} / \mathrm{dl}$ と上昇し たのを最高に終始10〜17mg/dlを保つた. 移植腎の組織学 的検索例も，拒否反応の所見を欠き，解剖の結果，気管 支肺炎によつて死亡したものと推定された.この拒否反 応を生じなかつた B-3 では， cytotoxic antibody は， 一度も証明されなかつた。

$\alpha_{2}$-globulin, $\gamma$-globulin はこの例では術前值が， $\alpha_{2}$-globulin $1,262 \mathrm{mg} / \mathrm{dl}, \gamma$-globulin $897 \mathrm{mg} / \mathrm{dl}$ と, 他犬 に比してやや高値を示したが，術後漸次下降の傾向を 示し，術後20日目には $\alpha_{2}$-globulin $756 \mathrm{mg} / \mathrm{dl}(-40 \%)$ ， $\gamma$-globulin 236mg/dl (-74\%) と下降を示している.

B-4 は predinisolone $2 \mathrm{mg} / \mathrm{kg} / \mathrm{day}$ と azathioprine $5 \mathrm{mg} / \mathrm{kg} /$ day といら比較的強力な免疫抑制処置を行な つていたが, 術後 8 日目頃から移植腎機能障害を生じ, 術後14日目に尿毒症により死亡した例である. 移植腎の 組織学的検索では，腎の拒否反応による破壞は強度であ つた. cytotoxic antibody は術後11日目に初めて証明

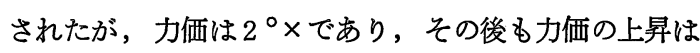

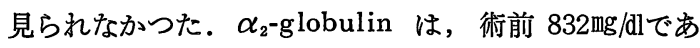
つたが，移植術後漸次增加し 8 日目には $2,133 \mathrm{mg} / \mathrm{dl}$ とピ 一クを示した後急激に下降し， cytotoxic antibody の 初めて証明された術後11日目には $488 \mathrm{mg} / \mathrm{dl} ， 13$ 日目には $384 \mathrm{mg} / \mathrm{dl}$ と, 術前の54\%減となつた. $\gamma$-globulin は逆

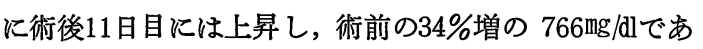
つた.

(小括)

$\mathrm{B}$ 群の平的生存日数は17.3日であつたが, そのうち， 拒否反応によつて死亡したものは B-2, B-4 の2 例であ つた. cytotoxic antibody の証明されたのは B-2, B-4 の 2 例に执いてのみであつたが, その抗体価はA群のそ れに比して低いものであり，その出現もほ注，拒否反応 が極期に達してから現れたものと思われる. cytotoxic antibody が証明されなかつた B-1，B-3 の移植腎は， 組織学的にも, 拒否反応の所見を欠いていた. $\alpha_{2}$-globulin は, 術後一過性に高値を示したが, BUN との相 関関係は認められなかつた. $\gamma$-globulin は, この抗免 疫処置群では, 術後漸次減少する傾向にあり, B-4 飞お。 いての及術後11日目に BUN が上昇し; cytotoxic an- 
tibody が証明されると同時に，増加の傾向を示した。

3. C群 (図 3 参照)

C群は，腎同種移植術を施行する際リシピエントの 固有の腎の摘出を片側のみに止め, 移植後, 5 日〜 9 日 後に移植した腎の摘出を施行し，その前後の cytotoxic titer, $\alpha_{2}$-globulin, $\gamma$-globulin の変動を観察したもの である.

C-1 は，移植後7 日目に移植腎の摘出を行なつた。 移植腎の組織学的検索では，拒否反応の所見が認められ た. cytotoxic antibody は移植後 7 日目までは証明さ

図 3

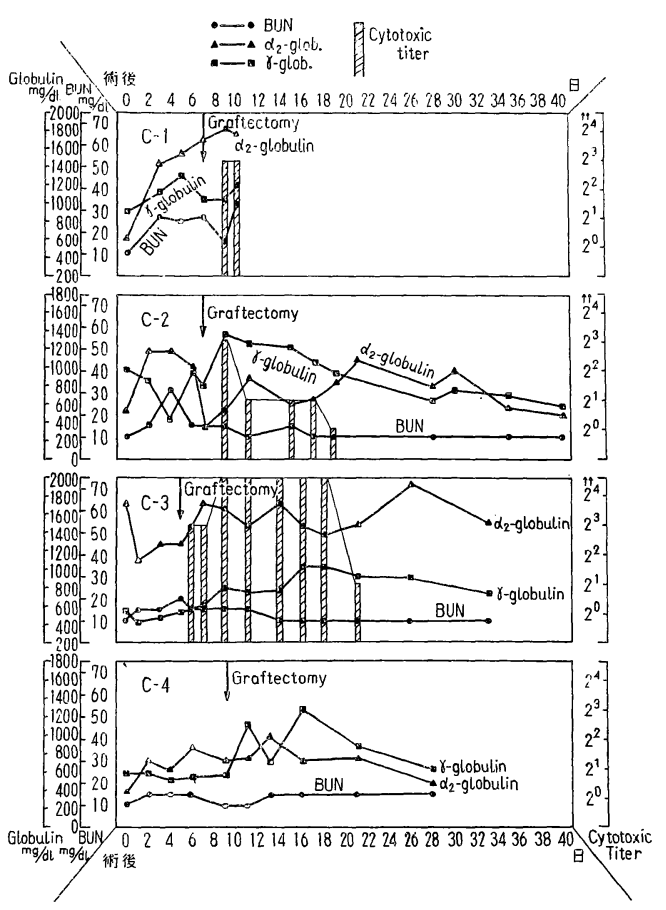

れず。移植腎摘出後 2 日目に， $2^{3} \times$ 力価の cytotoxic titer が血中に証明された。翌日（術後10日目）も $2^{3} \times$ の抗体が証明されたが, その後の追求は, 実験犬が逃亡 したためできなかつた。 $\alpha_{2}$-globulin は，移植前 590 $\mathrm{mg} / \mathrm{dl}$ 例あつたものが，術後 7 日目（移植腎摘施行当日） には $1,710 \mathrm{mg} / \mathrm{dl}$ ，移植腎摘出後む上昇し続け術後 9 日目 には $1,820 \mathrm{mg} / \mathrm{dl}$ 達した。一方 $\gamma$-globulin は術後 5 日 目まで漸次増加したが，移植腎摘出後は横這いないし軽 度の上昇を呈したのみで，期待したよらな移植腎倹出後 の急激な $\gamma$-globulin の増量は認められなかつた。

C-2 も，C-1 と同様に移植後 7 日目に移植腎の摘出を
行なつた。摘出された移植腎の組織学的検索では，中等 度の拒否反応が認められた。cytotoxic antibodyは， 移㥀腎摘出後 2 日目から血中に出現し始めた。 その力 価は，移植腎摘出後 2 日目 $2^{3} \times, 4$ 日目 $2^{2} \times, 7$ 日 目 $2^{2} \times, 9$ 日目 $2^{2} \times, 11$ 日目 $2^{\circ} \times$ で, 14 日目以後は antibody は検出しえなかつた。

$\alpha_{2}$-globulin は移植術前が $521 \mathrm{mg} / \mathrm{dl}$ ，術後 2 日目， 4 日目が $1,170 \mathrm{mg} / \mathrm{dl} ， 1,162 \mathrm{mg} / \mathrm{dl}$ と上昇後移植腎を摘出 した 7 日目には $350 \mathrm{mg} / \mathrm{dl}$ と減少，移植腎摘出後ふたたび 増加し，11日目（移植腎摘出後 4 日目）には $868 \mathrm{mg} / \mathrm{dl}$ 。 21日目には $1,088 \mathrm{mg} / \mathrm{dl}$ とピークに達した後次第に減少す る傾向をとつた。

$\gamma$-globulin は興味あるカーブを画いた。すなおち。 術前 980mg/dlであつた $\gamma$-globulin は，術後 4 日目交 で減少した後 6 日目にはほぼ術前値に復した。7 日目に 移植腎の摘出を行なつたが, それを境に上昇し2 日後 の，術後 9 日目には $1,363 \mathrm{mg} / \mathrm{dl}$ と58\%の增加を見た。そ の後は漸次ゆるやかに減少した。このCー2では, cytotoxic antibody の出現と, $\gamma$-globulin の增加が, 移 植腎摘出直後から時を同じくしている.

C-3 では, 移植術後 5 日目に, 移植腎の摘出を行なつ た。移植腎は組織学的に拒否反応を呈していたが，5日 目までは, 血中に cytotoxic antibody は検出されなか つた。しかし移植腎を摘出した翌日から $2^{3} \times$ の力価を 持つ cytotoxic antibody が血中に現れ始めた. 7 日 目（移植腎摘出後 2 日目）には，その力価は $2^{3} \times, 9$ 日目（同 4 日目）から18日目（13日目）なでは $2^{4} \times$ 以

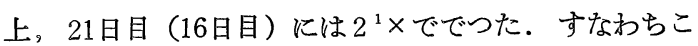
の例では,移植腎摘出の際に高力価の cytoxic antibody が現れ，腎摘出後16日間にわたつて血中に証明された. この間 $\alpha_{2}$-globulin は, 移植術後には減少し, 移植 腎摘出後旧值飞復し, 一方 $\gamma$-globulin は, 移植腎摘 出までは横這いてあつたものが，その後じょじょに増加 し，術後16日目には $1,021 \mathrm{mg} / \mathrm{dl}$ と，術前の約 $100 \%$ を示 した後, 漸次減少の傾向をとつた。

C-4 は，移植後 9 日目に移植腎の摘出を行なつた。移 植腎は組織学的に拒否反応を呈しながらる，cytotoxic antibody は, 腎摘前後に, 1 度も血中に検出されなか つた例である。 $\alpha_{2}$-globulin は，術後じよじよに增加 して 9 日目には術前の $86 \%$ 增の $722 \mathrm{mg} / \mathrm{dl}$ ，腎摘後も 4 日 間じよじよに上昇した後, 漸次減少の傾向を示した. $\gamma$ globulin は, 高力価の cytotoxic antibody が検出さ れた前は，C-3 と同様のパターンを示し，移植後横這 
い, 9 日目の脳摘出を境に, 11 日目，16日目の 2 つのピ 一クをむつて急激に増加し，16日目には術前の $129 \%$ 増 の $1,283 \mathrm{mg} / \mathrm{dl}$ となつた. その後かなり速い速さて減少 し, 術前值に近ついていつた.

\section{(小括)}

$\mathrm{C}$ 群では 4 頭の実験犬中， 2 頭は移植後 7 日目に， 1 頭は 5 日目に，残る 1 頭は 9 日目に移植腎摘出を行なつ た. cytotoxic antibody は 4 頭中 3 頭に現れ，いずれ も移植腎摘出後に血中に証明され，follow up のでき たC-2，C-3ではそれぞれ11日間，16日間血中に抗体を 証明しえた. $\alpha_{2}$-globulin は, C-3 犬の第 1 回手術後 $\gamma$-globulin の増加之高力価の cytotoxic antibody の 出現が 同時飞認められた。C- 4 犬では, $\gamma$-globulin は, 前述の C-2, C-3 と同様に, 移植腎摘出後急激に增 加したが, 血中には cytotoxic antibody は証明されな かつた.

\section{D群（図 4 参照)}

D群は，腎同種移植後 prednisolone $2 \mathrm{mg} / \mathrm{kg} / \mathrm{day}$ と azathioprine $5 \mathrm{mg} / \mathrm{kg} /$ day の免疫抑制処置を行ない, 術後 7 日目に移植腎の摘出を施行したものである.

D-1 は， 7 日目に摘出した移植腎が光顕的に明らかに

\section{図 4}

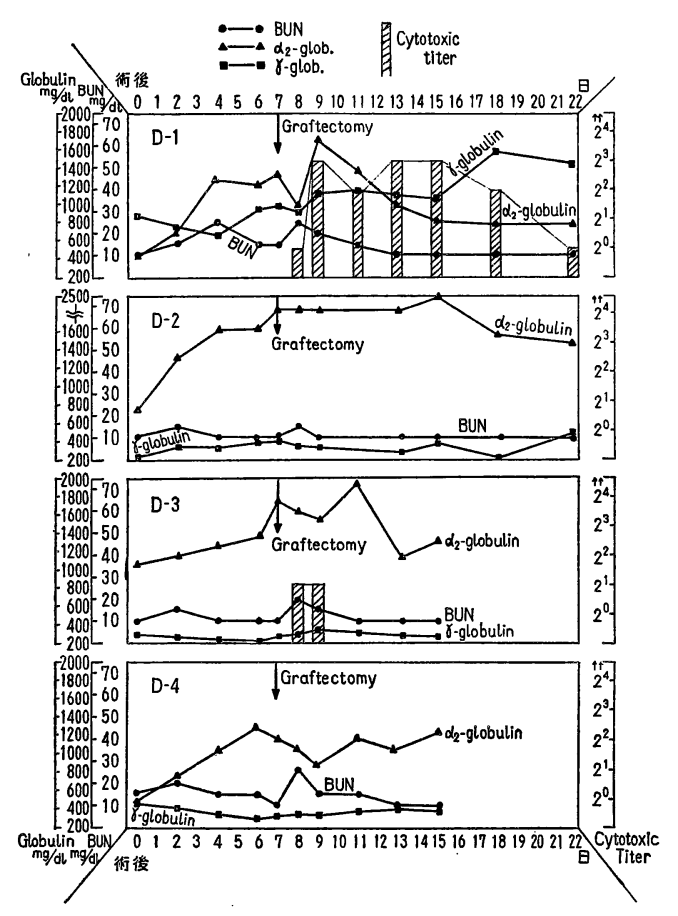

拒否反応を呈していたこの群で唯一の例である.

この例でも $\alpha_{2}$-globulin は移植術後上昇傾向を巡り 7 日目には術前値の $214 \%$ 増の $1,322 \mathrm{mg} / \mathrm{dl}$, 移植腎摘出 後も上昇し 9 日目には $1,728 \mathrm{mg} / \mathrm{dl}$ とピークに達した後し だいに減少し，15日目には799mg/dl と低下し以後横這い となつた。

$\gamma$-globulin は, 術後 4 日目までやや減少し, 7 日目 にはほぼ術前値 ( $864 \mathrm{mg} / \mathrm{dl})$ に復した. そして, 移植 腎摘出後増加の傾向を示し, 18日目（移植腎摘出後11日 目）には $1,584 \mathrm{mg} / \mathrm{dl}$ とピークに達した後, 漸減の傾向を 示した.

cytotoxic antibody は, 移植腎を摘出した翌日の 8 日目から血中に現れ，9日目には $2^{3} \times, 11$ 日目には $2^{2}$ $\times$, 13 日目，13日目，15日目はそれぞれ $2^{3} \times ， 18$ 日目 $2^{2} \times 22$ 日目には $2^{\circ} \times$ の力価であつた.

D-2 犬の, 移植腎の組織学的検索では, 拒否反応所見 は見られなかつた。 $\alpha_{2}$-globulin は術前 $730 \mathrm{mg} / \mathrm{dl}$, 術後 7 日目まで上昇し続け 7 日目には $193 \%$ 増の $2,176 \mathrm{mg} / \mathrm{dl}$ 移植腎摘出後も高值を保ち，15日目には $2,455 \mathrm{mg} / \mathrm{dl}$, そ の後漸減の傾向を示した. $\gamma$-globulin 值は術前より $235 \mathrm{mg} / \mathrm{dl}$ と低值を示し, 移植術後および移植腎摘出後も 明らかな変動を示さず， cytotoxic antibody る終始証 明されなかつた。

D-3 犬の移植腎の摘出標本は光顕的にも軽微な拒否反 応所見しか呈していなかつた. $\alpha_{2}$-globulin はこの例 でも, 移植術後增加を示し, 移植腎摘出後も11日目まで は増加し, その後術前値に復した. $\alpha_{2}$-globulin は, D-2 と同じく術前より低值で, 術前 $301 \mathrm{mg} / \mathrm{dl}, 7$ 日目 $276 \mathrm{mg} / \mathrm{dl}, 9$ 日目 $366 \mathrm{mg} / \mathrm{dl}, 15$ 日目 $285 \mathrm{mg} / \mathrm{dl}$ とほとんど変 化を見せなかつた. cytotoxic antibody は8 日目，9 日目（移植腎摘出後 1 日目， 2 日目）にの及, $2^{1} \times$ の 力価を有する抗体を証明した。

D-4 犬では，移殖腎は拒否反応を呈さず，流血中の cytotoxic antibody も証明されなかつた. $\alpha_{2}$-globulin は, 術前 $498 \mathrm{mg} / \mathrm{dl}$ であつたものが術後 6 日目まで上昇 し，6日目には $1,295 \mathrm{mg} / \mathrm{dl}$ と $133 \%$ の増加を示した後， じよじよに減少, 術後 9 日目には $886 \mathrm{mg} / \mathrm{dl}$, その後ふた たび増加を示し，15日目には 1,242 mg/dl であつた． $\gamma$ globulin は, 術前 $476 \mathrm{mg} / \mathrm{dl}, 6$ 日目 $296 \mathrm{mg} / \mathrm{dl}$, 8 日目 $350 \mathrm{mg} / \mathrm{dl}, 11$ 日目 $389 \mathrm{mg} / \mathrm{dl}, 15$ 日目 $396 \mathrm{mg} / \mathrm{dl}$ と大きな変 動は認められなかつた。

（小括）

抗免疫療法を行なつたD群では, 移殖後 7 日目に摘出 
表 2

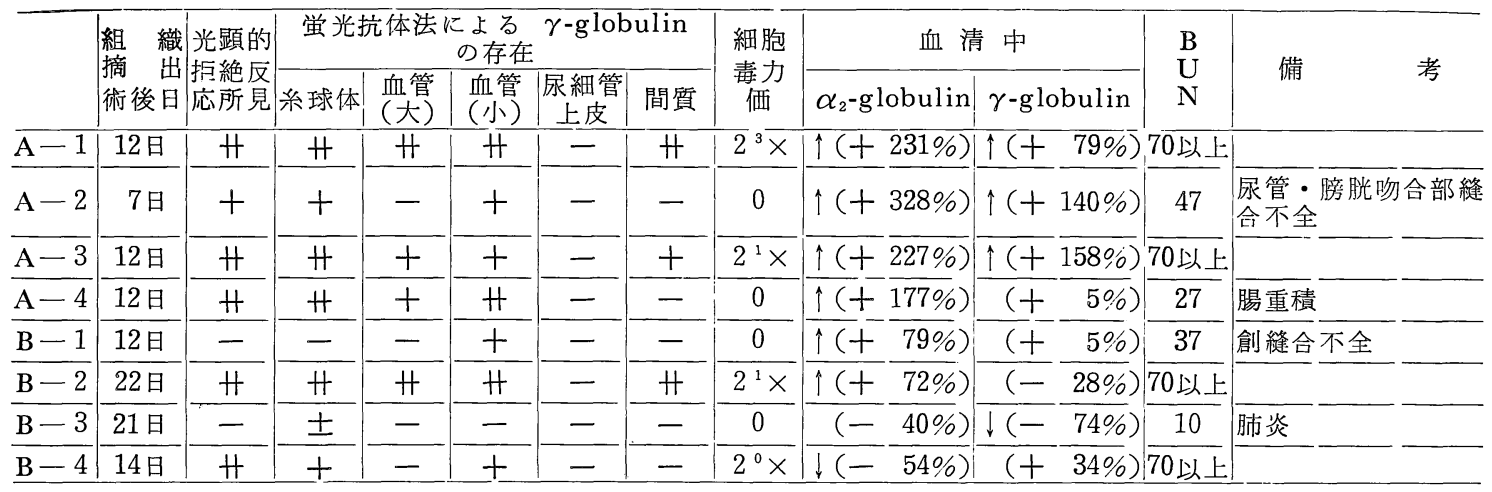

表 3

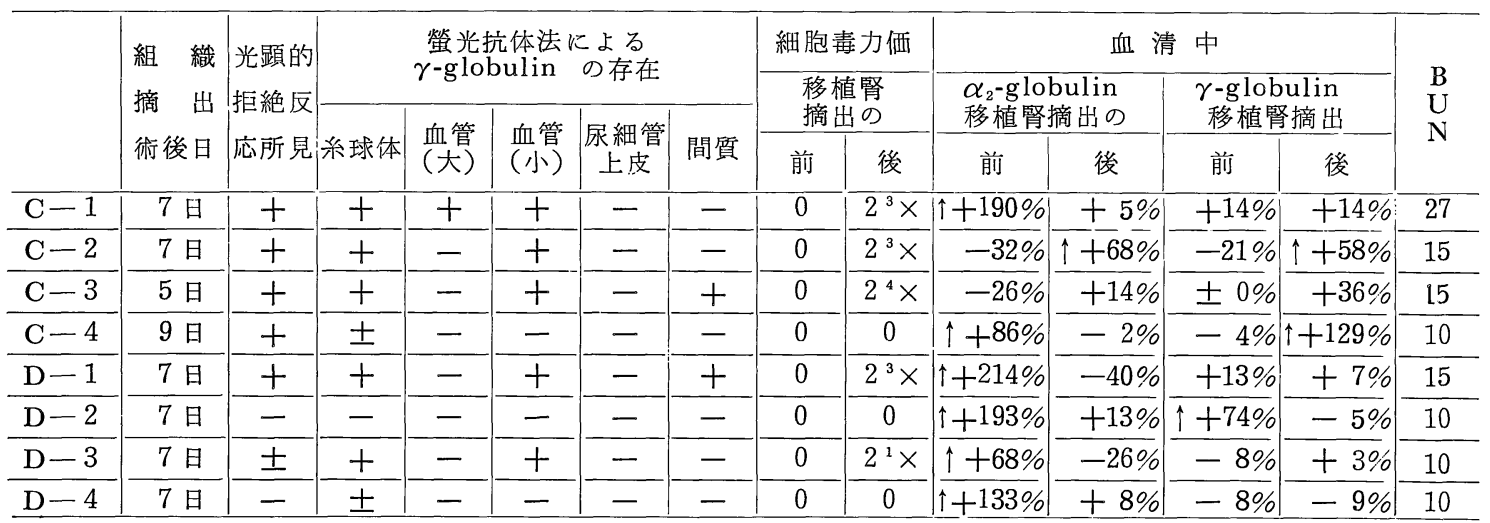

した移殖腎が，明らかに光顕的に拒否反応の所見を示し ていたものは D-1 のみであつた。この D-1 において， 移殖腎の摘出の際に, 流血中に cytotoxic antibody の出現をみ，また $\gamma$-globulin の増加が認められた。

D-3 に拈いて子移殖腎摘出後に cytotoxic antibody が認められたが，低力価で，その現れた期間も短いもの であつた。 $\alpha_{2}$-globulin はいずれにおいても術後ただ ちに上昇傾向が認められ，移殖腎摘出後も高值を保つも のが認められた。 $\gamma$-globulin 分画は D-1 を除く 3 例 では，有意の変動と思われるものは見られなかつた．

VI 蛍光抗体直接法による $\gamma$-globulin の移植腎へ の吸着（表一 2,3 , 図 5-9)

蛍光抗体液として anti-dog $\gamma$-globulin-rabbit-globulin-FITC を用いた今回の実験で， $\gamma$-globulin は移 植後 5 日の腎にすでに証明された。 $\gamma$-globulin は，糸 球体 tuft（C-3） は線状の沈着を起こし, 糸球体以外の 小血管，すなわち vas afferens, peritiubular artery
にもこまかい斑状の沈着として証明された，腎髄質内の 比較的大きな血管には 5 日目の移殖腎では $\gamma$-globulin は認められなかつた．光顕的に拒否反応の所見のより進 んだ移殖腎では，術後 7 日〜 12日目頃から，腎髄質内の 比較的大きな血管および腎間質にも $\gamma$-globulın の沈 着が認められた，血管壁への $\gamma$-globulin は内膜拉よ び内弾性板に非常に強度の蛍光を呈し，より深層にまで 斑状の沈着物が認められるものもある。間質への $\gamma$-globulin の沈着は, peritubular artery 户 venule を 中心に拡大して拉り，拈そらくはそれからの漏出による ものと思われる。腎間質に $\gamma$-globulin の沈着の認めら れたのは A-1，A-3，B-2，C-3，D-1 の 5 例であるが，い ずれも光顕的にも拒否反応の所見が高度 のものであつ た。またこの 5 例では，全例に cytotoxic antibody が， $2^{1} \times$ 以上に検出されたことは興味深い。

光顕的に，拒否反応の所見を欠いた B-1（術後12日）， B-3（同21日)，D-2（同 7 日)，D-4（同 7 日）飞扮いて 
図 5 糸球体 tuft への，こまかい顆粒状の $\gamma$-globulin の沈着

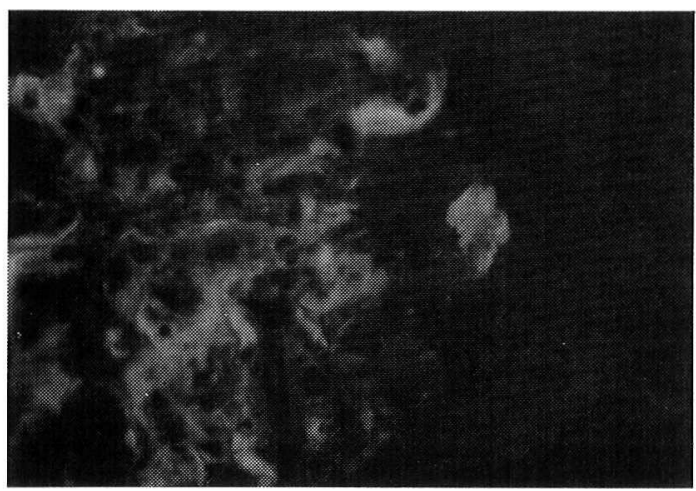

図 6 糸球体血管極へのより強度な $\gamma$-globulinの 沈着

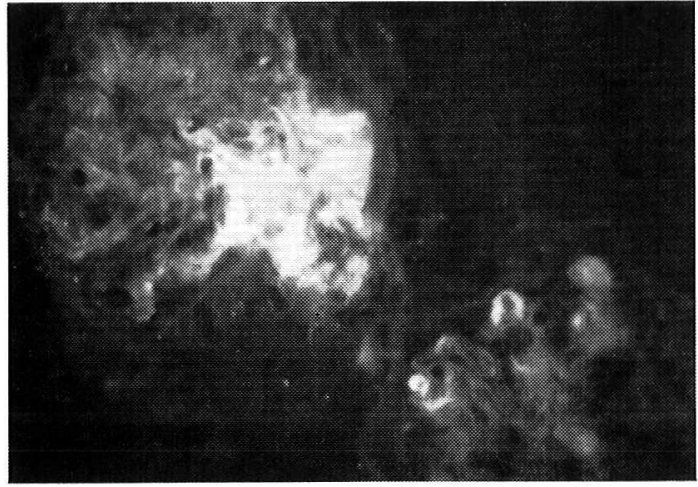

図 7 糸球体 tuff ヘのこ末かい線状の $\gamma$-globulin の沈着

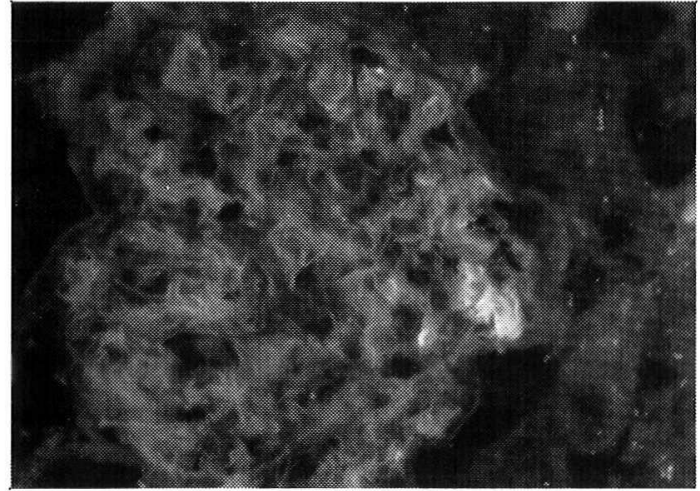

は, B-1 では, vas afferens, peritubular artery の よらな小血管壁にわずかに $\gamma$-globulin の沈着を認 め，B-3，D-4 では糸球体 tuft に微弱な線状の蛍光所
図 8 髄質内の比較的大きな血管ことに, その内 膜, 内弾性板への $\gamma$-globulin の沈着

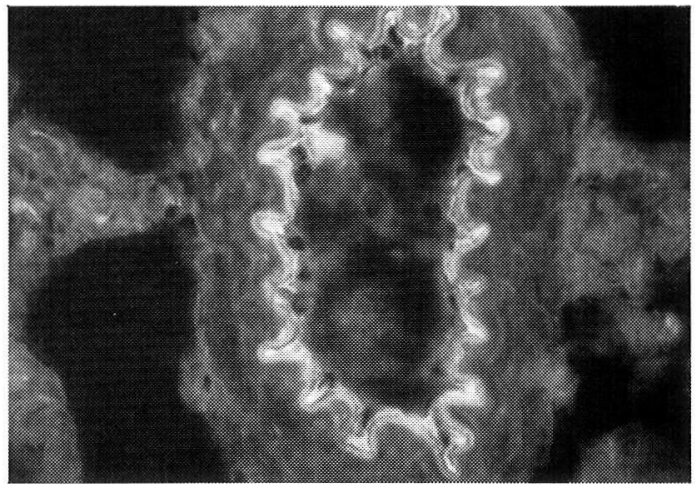

図 9 拒否反応のより進んだ移植腎での間質への $\gamma$-globulin の沈着

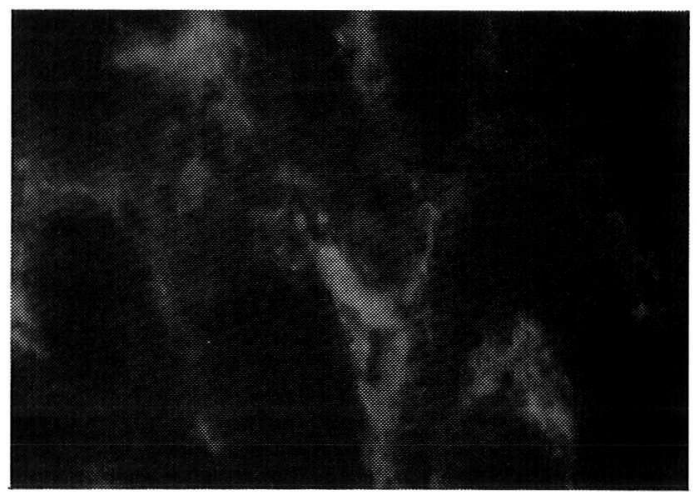

見が認められたに過ぎず，その他の糸球体，血管，間 質，尿細管上皮には $\gamma$-globulin の沈着は証明されな かつた．またこの組織学的に拒否反応の所見を欠き，著 明な $\gamma$-globulin の沈着を証明されなかつた 4 例では， いずれも血中に cytotoxic antibody が証明されなかつ た。

糸球体 tuft への $\gamma$-globulin の沈着の状態は, 線状 に，1つの糸球体全体にわたり，均一な状態で特異蛍 光を発するものが多いが，少数例に抏いては，血管極の 久に強い特晎営光を発するもの, あるいは系球体 tuft の一部のみに強い特異蛍光を発するものも認められた. また糸球体全体に蛍光を発する例では, 線状の蛍光が多 く，糸球体血管極のみ，あるいは糸球体の一部のみのも のでは顆粒状の $\gamma$-globulin の沈着が多く認められた.

腎内血管への $\gamma$-globulin の沈着は peritubular artery, venule, vas afferens のように小血管壁への 
斑状の沈着からはじまり，拒否反応の進行するにつれて 髄質内の比較的大きな血管壁, ことに内膜および内弾性 板への沈着へと進んで行く. 腎間質への $\gamma$-globulinの 沈着は上述のような拒否反応 のさらに高度のものに認 められ, peritubular artery p venule を中心に拡が るように思われる。また尿細管上皮への $\gamma$-globulin の 沈着は，まつたく見られず，尿細管腔では，ただ 1 例に おいて強い特異蛍光を発する細胞塊を認めた。

同一条件で施行した対照では， $\gamma$-globulin の沈着は 認められなかつた。をた,抗体吸収試験拉よび blocking test では，顕著な蛍光の減弱あるいは消失が認められ た.

\section{$\mathbf{v}$ 考 按}

(a) $\alpha_{2}$-globulin

血清蛋白の変動は, 各種疾患の診断や予後の判定に役 立つている.臓器移殖後の血清蛋白の変動についても， 枚挙のいとまのない程多数の報告がある. その内でも $\alpha_{2}$-globulin については, 移殖後その増加を認めた論文 が多いが，その評価に関しては，異論も多い。

1960年 West ${ }^{16)}$ らは，犬を用いた腎同種移殖，回腸 移殖後に血清中の $\alpha_{2}$-globulin が上昇することを述 べ，そしてこの $\alpha_{2}$-globulin の增加の主たるるのは glycoprotein であることを証明した。しかしながらっこ の $\alpha_{2}$-globulin の増加は腎盐腎炎のような非特異的炎 症や，Freund's adusvant や松脂の注射によつて生ず る無菌性濃演によつても生じ, これも同じ glycoprotein の増加による $\alpha_{2}$-globulin の増加であることが確めら れ, したがつて $\alpha_{2}$-globulin の増加は移植臓器の拒否 反応関与する抗原 一抗体反応 の一部であるといらよ り, むしろ拒否された臟器内に存在する 2 次的な炎症反 応に対する反応として生ずるるのであろらとしている。 $\alpha_{2}$-globulin が, 拒否反応を起した臟器を摘出した後で も上昇し続けるといら事実は，それが炎症を生じている その病巣から産出されるものではなく，何かの刺激に対 する反応として，どこかで産出されるものであろうとす る考方方に，著者も同意するが，それに加兄て，その藏 器を摘出するのに第 2 回目の手術的侵襲がさらに加光ら れているといら事実も考慮に入れられるべきであららと 考光る。

腎以外の臟器については，1966年 Kukral ら ${ }^{17}$ は， やはり犬を用いた肝同種移殖後に $\alpha_{2}$-globulin が上昇す ると述べ，この $\alpha_{2}$-globulin 分画の上昇は肝自家移殖 後にも同様のパターンを認めて拈り，拒否反応に特異的
なものではないとしている。

これより先，1965年に Weimer \& Benjamin ${ }^{18)}$ は， 爯を用いた実験で， $\alpha_{2}$-AP (acute phase) globulin の 存在を提起した。すなわち, かれらは松脂を注射して無 菌性膿瘍を作つた鼡の血清中に，正常监血清中には証明 されない蛋白を，兔疫化学的方法で検出し，これを $\alpha_{2}$ AP-globulin と名付けた. そして, この $\alpha_{2}$-AP-globulin は炭水化物を含む euglobulin で濾紙扰よび寒天を 用いた電気泳動では $\alpha_{2}$-globulin の移動度を有し， ア クリルアミドや激粉ゲルを用いた場合には非常に低い移 動度を有し，macroglobulinに属すると述べている。続 いてかれらは $\alpha_{2}$-AP-globulin と C-reatieve protein, Cx-reative protein との異同につき言及し。それ らが，正常血清中には存在せず，組織損傷のあとに出現 すること，抗原性を持つこと，globulin であることな ぞでは共通した性格を持つているが，抗原的に両者は異 つたもので, 硫酸アンモモウム液への溶解度, 電気泳 動による移動度,カルシウム・イオンの存在下に拈ける C-polysaccharide による沈降反応などに扣いて相異る ものであると述べている.

一方， $\alpha_{2}$-globulin の上昇が，移殖腎の拒否反応あ るいは, 耐容 (tolerance) に特異的なものであるとす る意見があり，それは Riggio ら ${ }^{199}$ ，の論文に代表さ れる. かれらは26名の腎移殖臨床例について検討し，拒 否反応を起こした17名に，20.7\%～212.3\%の $\alpha_{2}$-globulin の上昇を認め, 28回の拒否反応の内, 17回の拒否 反応では $50 \%$ 以上の上昇が認められ，その平均は $70.2 \%$ (士42.1\%)であると報告している. しかし $\alpha_{2}$-globulin の上昇はいずれも臨床症状，あるいは検査成績が，腎機 能の変動を示した後に現われることも付け加えている. また前に述べた West らや Weimer \& Benjamin らの 実験結果と異る点は, 急性腎孟腎炎や後腹膜腔膿瘍など の細菌感染によつて,重篤な臨床症状を呈した場合にも。 $\alpha_{2}$-globulin の上昇を認めていないことである。これは 人と犬または鼡との実験動物の違いによる血清蛋白の相 違によるものとも考光られる。さらに $\alpha_{2}$-globulin の上 昇が，1例を除く全例に和いて glycoprotein の増加に よることを認めているが，その glycoprotein 增加の 主因が haptoglobulin, cerculoplamin, $\alpha_{2}$-globulin orsomucoid のいずれの增加によるものかについては結 論が出されていない. Riggio らはこのように拒否反応 の場合に $\alpha_{2}$-glycoprotein が増加し, 細菌感染や原発 性腎疾患では，それが認められないということで，この 
蛋白質が拒否反応または耐容のどこかの相と特異的な関 係があるのではないかと述べている.

また, この， $\alpha_{2}$-globulin が，耐容と深い関係にでる のではなからうか, ということについては, Mowberay や Mannic \& Schmid の興味ある論文がある.1963年 Mowbra ${ }^{2021)}$ は, 正常の哺乳類の血清から DEAE セ ルローズ・カラム・クロマトグラフィーでえた（ 0.5 M acetate buffer) $\alpha_{2}$-globulinを，家鬼や鼡の皮膚 移殖け際リシピェントに注射して，移植皮膚生着期間の 延長を認め，また通常の抗原に対する circulating antibody の生成が，この $\alpha_{2}$-globulin の注射によつて 抑制されることを報告した。 しかしそれを追試した Davis \& Boxer $(1965)^{22)}$, Spiegelberg \& Weigle $(1964)^{23)}$ のそれを否定する報告の故に $\alpha_{2}$-globulin の 免疫抑制効果に対する興味も失われがちであつた. 1967 年になつて Mannnick \& Schmid ${ }^{24)}$ は, ACD 加保 存血から，血清 $10 l$ を集め Mowbray の方法よりも， より稀薄な 0.2Mの acetate buffer で, elute したB 分画を，皮膚移殖の実験に用いて，やはり移殖皮膚の生 着期間の延長を認めたとし，ふたたび $\alpha_{2}$-globulin の 抗免疫効果が注目を集め始めた．続いて1968年 Cooperbend et $\mathrm{al}^{25)}$ らは in vitro の実験で，正常人血清の $\alpha_{2}$-globulin が免疫抑制効果を持つと述べている.

このように， $\alpha_{2}$-globulin の抗免疫効果が，注目さ れ始めているが，その作用機序については，いまだ仮説 の域を脱しない. Currie \& Bagshawe ${ }^{26)}$ は, $\alpha_{2}$-globulin 中の Sialomucin が, 陰性に帯電した glycoprotein であるので，それが抗原の表面に付着して被覆し ているの例はなかららかと述べているが， $\alpha_{2}$-globulin

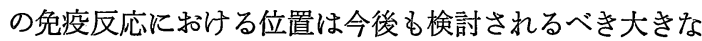
課題を多数かかえていると言兄よう．Kamrin ${ }^{27)}$ が指 摘しているように，特異的な $\alpha_{2}$-glbulin に同位元素 をラベルして radioautography 扤よび 蛍光顕微鏡を 用いれば，免疫反応と関係ある細胞の表面に存在する特 殊な $\alpha_{2}$-globulin 粒子を発見することが将来できるか も知れない.

(b) $\gamma$-globulin

移植免疫と $\gamma$-globulin との関係について, 多数の 研究がなされているが，その結論はなかなか出とうにな い. 移植免疫は，細胞性抗体と体液性抗体のいずれか， またはその両者から成り立つている以上，一刀両断に結 論が出ないのも止むをえない，一言に移植免疫といつた ところで，同種移植と異種移植とでは，それに関与する
抗体は態度を異にするであろうし, 腎・肝・心のように 直接血管同志の吻合を必要とする臓器と, 皮膚移植とで は抢のずと差が生じても不思議ではない。

犬を用いた実験的心移植において，隅田ら ${ }^{28}$ は無処置 群では移植後 $\gamma$-globulin の増加を認め, methotrexate, prednisolone $\mathbf{X}$ 線照射などによつて移植心の生着 延長が得られたものでは， $\gamma$-globulin の増加は抑制さ 机たとして, $\gamma$-globulin の藏器移植前後の変動飞注意 を促している。

一般に抗体産生の時期については, 初期には IgM 抗 体が増加し, 少し遅れて IgG 抗体が増加することは知 られているが，Phillips ${ }^{29)} \mathrm{Nagi}^{30)}$ は，それぞれ，は つか営，家鬼を用いた皮膚同種移植の実験を行ない，移 植後 4 日目頃から IgM globulin の産生が増加し次い で拒否反応と時を同じくして, IgG globulin が増加す ることを報告している，腎同種移植については，鼡を用 いた実験で，1968年 Spong ら ${ }^{311}$ はIgG, IgM globulin に，組織適合性抗体が存在することを明らかにした，そ して抗体価の高いIgG を注射することによつて，腎の 細小動脈壁への単核細胞の浸潤が生ずることをも付け加 えている。

腎同種移植臨床例に括いて，大越ら ${ }^{32}$ は拒否反応と時 を同じくして IgG globulin の增加, 補体の第 3 成分 である $\mathrm{B}_{1} \mathrm{C} / \mathrm{B}_{1} \mathrm{~A}-$ globulin の急激な減少が認められた と報告した。

$\mathrm{B}_{1} \mathrm{C} / \mathrm{B}_{1} \mathrm{~A}$-globulin については, Carpenter $5^{33)}$ も, その変動と拒否反応との関係が興味深いものであると述 べている，この補体の低下は，遅くなつてから生ずる complement fixing antibodies の出現 ${ }^{34)}$ とるるのか も知れない.

(c) Cytotoxicity

腎移植後血中に cytotoxic antibody の出現を, 臨 床例で最初に報告したのは1967年の Morris ら $^{35}$ の論文 である. かれらは同種のリンパ球ドナーからリンパ球を 集め, Terasaki ${ }^{36)}$ の microcytotoxicity test を行 なつて，腎移植後の患者の血清飞 cytotoxic antibody が出現することを認め，これらの血清は組織適合検查用 血清の供給源になりらることを示唆した. るつとも，動 物実験では, 1964年にすでに Altman \& Simonsen ${ }^{37)}$ が，腎移植後流血中に cytotoxic antibody を証明して いる.

1968年には Morris ${ }^{38)}$ らは，41名の臨床例について 同種リンパ球に対する cytotocix titrationを行ない, 
cytotoxin 陽性の患者の移植腎機能は失敗に終る傾向に あると述べた。続いて Manzler ${ }^{39)}$ は，腎ドナーのリン ハ球に対する cytotoxic antibody は，14名中 5 名が陽 性で, その内 4 名が急性拒否反応に兴み cytotoxic antibody の出現は臨床的に拒否反応の診断が下される以 前であることから，腎ドナーのリンパ球に対する cytotoxic titration の重要性を説いている。これに関して は, Stewart ${ }^{40)} ら$, Patel ら ${ }^{41)}$ も同意見で,Stewart ら は，同種リンパ球に対する cytotoxicity が陽性であり ながら，ドナーリンパ球との cytotoxicity が陰性で 移植後相当長期間良好な腎機能を営しだ 2 名を報告して いる。また，Patel らは移植前にドナーのリンパ球と リシピェントの血清との間に, cytotoxicity testを施 行し，陽性であつた 30 名中 24 名に移植後急激な腎機能障 害を認めた一方，陰性であつた 195名中，移植後急激 な腎機能障害を認めたものはわずかに 8 名で，有意の差 （P<0.01）があり，術前すでにドナーに対する cytotoxin の認められるといらことは，移植の禁忌であると 述べている。

こうした cytotoxic antibody は, $\gamma$-globulin 分画 中のどの部分にあるか，といらことに関して，Mc. Donald は，IgG (7S) に新艺らくあるのだろらに述べて いる。一方 anti-globulin consumption test で証明 されるるのは IgM (19S) 抗体だとしている.

1968年 Dubernard らは ${ }^{42)}, \operatorname{Dog}$ A から Dog B に腎同種移植を行ない, cytotoxic titter の上昇を待つ て Dog Bから採血し，その血清をDog A の残つたひと つの腎の腎動脈から注入して，急激な腎機能低下をきた した例を報告した。また正常な血清を腎動脈に注入して も腎機能不全を起こさないことから，これは cytotoxic titter の上昇した血清による移植免疫の受動的移入であ るとしている．組織学的には糸球体の細胞增多、メサン ギウムの濃縮化，基底膜肥厚，蛋白円柱が認められ，皮 質には小血栓を伴う急性腎皮質の壊死が認められたと述 ベている。

著者の実験では, 同種リンパ球に対する cytotoxic antibody が検出されなかつたにもかかわらず，移植腎 に拒否反応が進行している場合があつた。この原因とし て, (i) cytotoxic titration に用いたリンパ球のドナ 一犬の数が少ないために，腎のドナー犬とリンパ球のド ナー犬との間に共通した組織適合抗原が存在しなかつた のか，（ii）非常に多量の抗原である移植腎に流血中の 抗体が吸収され見かけ上陰性であるのか，(iii）Cyto- toxin negative absorption 陽性の抗体によるものか， の3つが考えられる.

(d) 蛍光抗体所見

同種移植腎 の免疫組織学的追求は 1958 年 Linquist $ら^{43)}$ に始まる。かれらは，䋞に和ける腎同種移植で，早 期に細小動脈に immunoglobulin を見出した。1965年 には，Horowitz ら ${ }^{44)}$ が，犬を用いた同種移植腎の血 管上に $\gamma$-globulin の沈着が認められたと述べている。 1967年に Williams ら ${ }^{45}$ は，17名の移植腎の糸球体や 血管に $\gamma$-globulin の沈着を認めたが，拒否反応との 相関関係は認め難いとした。翌1968年には,Porter ら ${ }^{46)}$ は immunoglobulin, 補体, 線維素の沈着を糸球体に 認めたが，やはり拒否反応との相関関係は認め難かつた と述べている。それに対して1968年,'Mackenzie, Whittingham ${ }^{47)}$ は immunogloblin の移植腎の 糸球体拈よ び血管壁への沈着は，拒否反応と非常に密接な関係にあ ると述べた。すなわち，28名の臨床例から計82回の免疫 組織学的検討を行なつて，拒否反応を起こしている間の 腎の血管壁, 糸球体に immunoglobulin, 補体, 線維 素の沈着が著明に認められ，拒否反応を起こしていない 腎（14名）や拒否反応の収まつた後の腎組織には，それ らの沈着がより少なかつたと報告している。かれらはま た, immunoglobulin, 補体, 線維素の沈着があつて, albumin, $\alpha_{2}$-macroglobulin の沈着が認められないこ とから，これらの所見は，血清蛋白成分の非特異的沈着 といらより，特異的免疫反応によるものであろうと述べ ている。

今回の実験の結果では，すでに述べたように， $\gamma$-globulin の沈着は, 移植後 5 日目から, vas afferens, peritubular artery，venule，のような細小管壁や綠 体 tuft に線状にあるいは顆粒状に現われ，しだいに腎 髄質内の比較的大きな血管の内膜，内弾性板に現われ た．拒否反応のより進んだ腎ではとれらの $\gamma$-globulin の沈着はより強度となり，ついには腎間質にまで現われ るようになる。免疫抑制処置が効を奏して，拒否反応を 起こさないか。軽微である例では， $\gamma$-globulin の沈着 は微弱なるのであるか、侣とんど認められなかつた。

糸球体に批る $\gamma$-globulin の沈着の状態には, 前 述のようにほぼ均一に線状な沈着を示すものと血管極な いしは tuft の一部に 顆粒状な沈着を示すものがあつ た。糸球体腎炎に和ける糸球体 tuftへのimmoglobulin の線状の沈着は，基底膜抗原と抗体との反応を意味し。 顆粒状の沈着は circulating antigen-antibody com- 
plex の沈着である ${ }^{49)}$ とする説があるが, 臓器同種移植

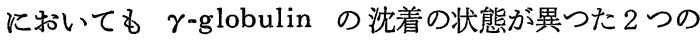
形状をとることは興味深い。しかしながら，そうした沈 着の状態の相異と，拒否反応の程度との間には明らかな 関係を認めえなかつた。

以上述べた蛍光所見につき，その特異性を証明するし めに, 正常腎, 抗体吸収試験, blocking test を行なつ たが，正常腎には上に述べたような蛍光は認められず， 抗体吸収試験および bloking test により著しい蛍光の 微弱化拉よび消失を認めたことから，前述の蛍光所見 は，特異的免疫反応による $\gamma$-globulin の沈着で，腎 同種移植の拒否反応に和いて, cytotoxic antibody と 態度を同じくする，体液性抗体の重要性を示するのであ ると考觉る。

\section{VI 総括および結語}

拒否反応の血清学的診断の 1 つの手掛りとして, 雑種 成犬を用いた腎同種移植 4 実験群 飞扮いて，血清 $\alpha_{2}$ globulin, $\gamma$-globulin, cytotoxic antibodies $の$ 経時的 検索を行ない, それらと BUN, 光顕的拒否反応の検索， および自家製抗犬 $\gamma$-globulin 家鬼 globulin-FITCを 用いた，蛍光抗体直接法による免疫組織学的検索を併せ 行なつた.

その結果をまとめると次のようになる。

(1) $\alpha_{2}$-globulin は, 術後 BUNの上昇と平行して 増加するが，術後短日時で現われる急性拒否反応では， 非特異的炎症性血清反応による $\alpha_{2}$-globulinの増加と, 重なり合うことがあり，犬では $\alpha_{2}$-globulin の増加を すぐに拒否反応と結びつけることはできないように思わ れる。

（2） $\gamma$-globulin 分画は，ほ湆拒否反応が完成され た後に増加するものが多い.

また，免疫抑制処置群では，拒否反応時の $\gamma$-globulinの增加はより軽微で, 免疫抑制処置が奏効したもの では，減少するものが認められた。

$\gamma$-globulin の増加と, cytotoxic titer の上昇の時 期とはかならずしも平行関係にない.

（3）同種リンパ球に対する cytotoxic antibodiesの 陽性例では, 組織学的に $100 \%$ 拒否反応の所見が認めら れ，また BUN の上昇が認められた。

（4）同種 リンパ球に対するが検出されず，乙かも移 植腎の拒否反応が進行している場合がある（仮性陰性）。

(5) Cytotoxic titration は，移植腎の拒否反応の 血清学的診断方法として, 近い将来利用しうるものと考
えられる。

そのためには，リンパ球ドナーとしては，同種ドナー を用いるより，腎ドナーを用いた方が良く，したがつて リンパ球の保存の普及が望を机る ${ }^{50)}$.

さらに純度の高いリンパ球浮遊液を cytotoxic test に用いることが必要である ${ }^{51)}$.

（6）蛍光抗体直接法を用いて， $\gamma$-globulin の移植 腎への沈着の状態を検索した.

無処置群・免疫抑制処置群 ともに BUN の上昇と, $\gamma$-globulin の移植腎内沈着の状態, Kincaid-Smith 飞 よる光顕的拒否反応の所見はほぼ一致する.

$\gamma$-globulin は，無処置群では移植後 5 日目からすで $飞$ glomerular capillary, peritubular capillary $飞$ 認められ，7〜12日後には vas afferens, a. interlobularis，a. arorata としだいに大きな血管壁（ことに内 膜・内弾性板）に認められるようになる.

拒否反応のより進んだ例では，腎間質にも $\boldsymbol{\gamma}$-globulin の沈着を生じ，上に述べた血管系への沈着も同時に 増加するものが多いが，尿細管上皮には，最後まで特異 蛍光は認められなかつた。

稿を終劣るに当り, 御校閲下さつた恩師・大越正秋教 授に深甚なる謝意を表します。

また, 直接指導下さつた, 慶応義塾大学泌尿器科学教 室-中村宏博士, 同病理学教室坂口弘助教授, 動物実験 に際し助力を惜しまれなかつた泌尿器科学教室・腎移植 研究班の諸兄, 研究設備を快くお貸し下さつた病理学教 室の各位, 東京国立第 2 病院・細菌科小沢博士に心から の謝意を表します。

なお，この論文の要旨は第57回, 日本泌尿器科学会総 会にて発表した。

なお本研究の研究費の一部に, 福沢諭吉基金よりの補 助を受けた。

\section{文献}

1) Medawar, P.B.: J. Anat., 78, 176, 1944.

2) Medawar, P.B.: J. Anat., 79, 157, 1945.

3) Mitchson, N.A., and Duke, O.L.: J. Exper. Med., 102, 179, 1955.

4) Najarian, J.S. and Feldman, J.D.: J. Exper. Med., 115, 1083, 1962.

5) Terasaki, P.I. et al.: Ann. New York Acad. Scien., 99, 645, 1962.

6) Altman, B.: Ann. Roy. Coll. Surg. England., 33, 79, 1963.

7) Good, R.A. et al.: Ann. New York Acad. Scien., 64, 924, 1957. 
8) Najarian, J.S. et al.: Ann. Surg., 164, 398, 1966 .

9）中村宏：移植， 1, 434, 1967 。

10）小川恕人活か: 生物物理化学, 11，75，1966。

11) Peetoom, F.: The agar precipitation technique and it's application as a diagnostic and analytical method. Illionois. 1963.

12) Altman, B. and Simonsen, M.: Ann. New York Acad. Scien., 120, 128, 1964.

13) Nakamura, $H$. et al.: Surg. Forum. 19, 182, 1968.

14）安田健次郎活か：モダンメディフ,8, 438, 1962 .

15) 浜島義博, 京極方久: 免疫組織学。医学書院, 1965 .

16) West, C.D. et al.: Ann. New York Acad. Scien 87, 522, 1960.

17) Kukral, J.C. et al.: Surg. Forum., 18, 218, 1966.

18) Weimer, H.E. and Benjamin, D.C.: Am. J. Physiol., 209, 736, 1965.

19) Riggio, R.R. et al.: Lancet, i, 1218, 1968.

20) Mowbray, J.F.: Immunol., 6, 217, 1963.

21) Mowbray, J.F.: Fed. Proc., 22, 441, 1963.

22) Davis, W.C. and Boxer, L.A.: Transplant., 3, 673, 1965.

23) Spiegelberg, H.L. and Weigle, W.O.: Proc. Soc. Exp. Biol. Med., 117, 413, 1964.

24) Mannick, J.A. and Schmid, K.: Transplant., 5, $1231,1967$.

25) Cooperbend, S.R. et al.: Science, N.Y. 159, 1243, 1968.

26) Currie, G.A. and Bagshawe, K.D.: Lancet, i, 708, 1967.

27) Kamrin, B.B.: Transplant. Proc., 1, 506, 1969

28）隅田幸男, 平野敬八郎：移植, $2,175,1967$ 。

29) Phillips, M.E.: Lab. Inv., 19, 539, 1968.
30) Nagi, J.: Acta. Haemat. Jap., 31, 182, 1968.

31) Spong, F.W. et al.: J. Immunnol., 101, 418, 1968.

32) 大越正秋注か：生物物理化学, 14, 73, 1969。

33) Carpenter, C.B. et al.: Transplant., 5, 865, 1967.

34) Austin, K.K. and Russel, P.S.: Ann. New York Acad. Scien., 129, 657, 1966.

35) Morris, P.J. et al.: Surg. Forum., 18, 270, 1967.

36) Terasaki, P.I. et al.: Transplant., 5, 1057, 1967.

37) Altman, B. and Simonsen, M.: Ann. New York Acad. Scien., 120, 28, 1964.

38) Morris, P.J. et al. : Transplant., 6, 392, 1968.

39) Manzler, A.D.: Transplant., 6, 787, 1968.

40) Stwewart, J.H. et al.: Lancet, i, 176, 1969.

41) Patel, R. et al.: New Eng. J. Med., 280, 735, 1969.

42) Dubernard, J.M. et al.: Surg., 64, 752, 1968.

43) Linquist, et al.: Advance in transplantatino. 1611. Copenhagen. 1958.

44) Horowitz, R.E. et al.: Transplant., 3, 318, 1965.

45) Williams, G.M. et al.: Surg., 62, 204, 1967.

46) Porter, K.A. et al.: Lab. Invest., 18, 159, 1968.

47) McKenzie, I.F.G. and Whittingham, S.: Lancet, ii, 1313, 1968.

48) Lerner, R.A. et al.: J. Exp. Med., 126, 989, 1967.

49) Unanue, E.R. and Dixon, R.G.: Advan. Immunol., 6, 1, 1967.

50) Rowe, A.W. et al.: Fed., Proc. 22, 170, 1963.

51）辻公美注か：移植，3,326,1968。

（昭和 45 年 1 月 23 日受付） 